\title{
DAMAR ALAM UNTUK INDUSTRI CAT
}

\author{
Oleh : \\ Wiwit Mei Guritno
}

\begin{abstract}
Penelitian ini ditujukan untuk memanfaatkan damar alam yang ada di Kalimantan Timur menjadi bahan untuk pembuatan cat. Setelah percobaan pendahuluan, dilakukan pecobaan yang dirancang menggunakan rancangan acak berblok dengan 4 (empat) kali pengulangan. Faktor percobaan adalah persentase damar dalam bahan cair $(40 \%, 50 \%$, $60 \%)$, dibentuk bersama terpentin dalam proses pembuatan cat, sebagai blok adalah pengencer (A dan B) yang dicampurkan kedalam produk cat ketika akan diaplikasikan. Sifat secara umum sesuai acuan SNI 06-4872-1998, Spesifikasi campuran cat siap pakai berbahan dasar minyak. Pengamatan khusus dilakukan terhadap sifat kekentalan, waktu kering sentuh dan padatan sisanya. Penelitian menghasilkan teknologi sederhana pembuatan cat dengan bahan damar alam dan teknologi tersebut menghasilkan produk cat berbasis minyak dengan kategori tipe 3 (tidak terang) kelas $A$ (sedang). Penelitian ini menyimpulkan bahwa persentaase damar yang optimum adalah $50 \%$ dari bahan cairnya. Penelitian menyarankan penggunaan pengencer tipe B karena jenis ini lebih tidak berbahaya terhadap kesehatan dan keselamatan lingkungan.
\end{abstract}

Keywords : damar, cat minyak, terpentin, kekentalan.

\section{PENDAHULUAN}

alimantan Timur memiliki hutan yang luas. Hutan ini potensial menghasilkan damar dan potensinya dapat mencapai 2,8 juta ton per tahun. Perdagangan damar di Kalimantan Timur dapat ditingkatkan bila pelaku bisnis mengolahnya menjadi produk yang mempunyai nilai tambah lebih tinggi. Dengan kata lain perlu ada usaha industri skala lokal yang dapat memanfaatkan damar alam di Kaltim. Dari berbagai manfaat damar dan produk turunannya, tampak bahwa mengolah damar menjadi cat merupakan salah satu pilihan yang mungkin. Oleh karena itu dilakukan penelitian lebih seksama mengenai aspek teknologi pembuatan cat dari damar alam yang ada dan diperdagangkan di Kalimantan Timur.

Tujuan penelitian ini adalah untuk memanfaatkan damar alam yang ada di Kalimantan Timur menjadi bahan baku pembuatan cat. Sasaran penelitian adalah diperolehnya teknologi proses pembuatan cat dari damar alam dengan menggunakan bahan baku damar lokal, serta diperolehnya komposisi optimum proses pembuatannya. Penelitian mencakup penggunaan damar alam asalan (campuran berbagai kualitas) di Kalimantan Timur, percobaan pembuatan cat, penentuan komposisi optimum dan analisa aspek teknis proses pembuatan damar.

Diharapkan dengan tercapainya tujuan dan sasaran penelitian, usaha perdamaran di Kalimantan Timur dapat meningkat dan ada pelaku usaha yang bergerak di pengolahan damar alam untuk produk cat di Kalimantan Timur.

\section{DAMAR}

Damar adalah resin alam yang dihasilkan oleh dan keluar melalui torehan pada batang pohon berfamili Dipterocarpaceae dan Burceraceae. Terkait dengan sifat fisik dan kimianya, damar dapat digunakan sebagai salah satu bahan untuk produk-produk industri seperti cat, lilin, vernis, plastik, korek api, bahan isolatif, bahan pencetakan dan industri bahan peledak. Damar merupakan padatan rapuh dengan warna yang umumnya pucat kekuning-kuningan hingga hitam (tergantung jenisnya), memiliki sifat mudah terbakar dan bukan termasuk bahan yang mudah menguap bila tidak terdekomposisi. Tabel berikut menampilkan data lebih rinci sifat-sifat fisik damar. Damar 
hanya larut sebagian dalam alcohol dan eter, dan terlarut dengan baik dalam minyak terpentin dan petroleum eter.

Tabel sifat fisik damar

\begin{tabular}{|l|c|c|}
\hline \hline Sifat & Satuan & Nilai \\
\hline Titik lunak & $\mathrm{C}$ & $67-80$ \\
\hline Titik leleh & $\mathrm{C}$ & $96-114$ \\
\hline Indeks bias & - & $1,555-1,536$ \\
\hline Berat Jenis & - & $1,03-1,06$ \\
\hline Kekentalan 50\% toluene & $\mathrm{Cp}$ & $18,1-20,6$ \\
\hline Bagian yang tidak larut dalam alcohol & $\%$ & 23,4 \\
\hline \multicolumn{1}{c|}{-- dalam Aseton } & - & 17,9 \\
\hline \multicolumn{1}{c|}{-- dalam Petroleum eter } & - & 6,0 \\
\hline \hline
\end{tabular}

Sumber: Zuinely dkk. (1994)

Secara kimiawi, umumnya penyusun damar dikelompokan kedalam golongan ester resin, asam resin dan resen. Asam resin merupakan senyawa kompleks, memiliki bobot molekul yang tinggi (berupa polimer) dan mengandung satu atau lebih gugus hidroksil. Sedangkan resen adalah senyawa yang mengandung oksigen, tidak bereaksi dengan basa dan bukan merupakan alcohol, ester, asam keton maupun aldehid (Zulnely dkk,1994), lihat table komposisi damar.

Tabel komposisi damar

\begin{tabular}{|l|c|}
\hline Penyusun & Bagian (\%) \\
\hline Asam damarolat $\left(\mathrm{C}_{5,7} \mathrm{H}_{77} \mathrm{O}\right.$. $\left.(\mathrm{COOH})_{2}\right)$ & 23,0 \\
\hline A dammaresen $\left(\mathrm{C}_{7}, \mathrm{H}_{77} \mathrm{O}\right)$, dapat larut dalam alkohol & 40,0 \\
\hline B dammaresen $\left(\mathrm{C}_{3}, \mathrm{H}_{22} \mathrm{O}\right)$, tidak dapat larut dalam alkahol & 22,556 \\
\hline Abu & 3,5 \\
\hline Air & 2,5 \\
\hline Minyak atsiri & 0,5 \\
\hline Kotoran & 8,9 \\
\hline \hline
\end{tabular}

Sumber: Sadtler et.al. (1925) dalam Zulnely dkk. (1994)

Saat ini diperkirakan produksi damar menurun dengan drastis seiring menurunmya luasan hutan produktif tempat dimana damar alam dipungut akibat eksploitasi hutan yang sangat intensif beberapa dekade yang lalu. Penurunan juga sangat mungkin disebabkan oleh beralihnya mata pencaharian pelaku bisnis damar (pemungut dan pedagang) ke usaha lain yang lebih menguntungkan seperti usaha pertambangan atau bekerja sebagai buruh tambang yang saat ini sedang marak di daerah-daerah yang dulunya mengandalkan hasil dari damar. Tidak ada data yang akurat tentang penurunan ini, tercatat pada tahun 1998 Kaltim memperdagangkan 45.000 ton damar, yang jelas damar tidak banyak diperdagangkan lagi di Samarinda, Kutai Barat, Kutai Kartanegara dan Bulungan.

Dibalik semua itu, sebenarnya dengan luasan hutan produktif yang tersisa saat ini, potensi damar di Kaltim masih cukup besar. Dengan data dari Syahrudin dan kawan-kawan (1991) yang menyebutkan bahwa setiap hektar hutan produktif diperkirakan dapat diambil oleh pengumpul rata-rata $287,60 \mathrm{~kg}$ damar per tahun maka dengan luas hutan produktif sekitar 10 juta hektar (Keputusan Menteri Kehutanan No. 79/2001) diperkirakan akan dapat dipungut damar sebanyak 2.876.000 ton per tahunnya. Sulitnya potensi ini tersebar pada daerah yang sangat luas dan pemungutan hanya dapat dilakukan secara sporadis sehingga hasilnya tidak terlalu menguntungkan dan menarik minat pelaku bisnis.

\section{TERPENTIN}

Terpentin adalah cairan yang didapat melalui destilasi resin alamiah dari pohon, utamanya pohon pinus. la terdiri dari senyawa-senyawa terpen, utamanya monoterpen (alpa-pinene dan beta-pinene). Dua kegunaan utama terpentin dalam industri adalah sebagai pelarut organic dan sumber bahan dalam sintesa organik. Sebagai pelarut organik, terpentin digunakan untuk melarutkan dan mengencerkan cat yang berbasis minyak, untuk membuat pernis dan untuk bahan baku industri kimia. Menurut Jusko, D. (2007), terpentin melarutkan damar dengan baik dan juga merupakan pengencer terbaik untuk cat berbasis minyak. 


\section{CAT}

Biasanya cat terbuat dari bahan-bahan seperti resin (binder), pigmen dan ekstender atau pengisi, pelarut (solvent) dan bahan tambahan lainnya (additive). Resin merupakan komponen utama dalam cat yang berfungsi merekatkan (mengikatkan) bahan-bahan cat lainnya dan juga melekatkan keseluruhan bahan cat pada permukaan suatu bahan serta membentuk suatu lapisan (film). Resin untuk cat diklasifikasikan berdasarkan mekanisme pengeringan atau pengerasannya (pembentukan film) dan tiga diantaranya yang cukup penting adalah: penguapan solvent, reaksi dengan udara dan polimerisasi

Pigmen dan zat warna adalah sama-sama zat pemberi warna, yang membedakannya adalah jika zat warna bersifat larut dalam solvent maka pigmen tidak. Selain memberi warna, pigmen juga berfungsi memberi daya kilap atau daya tutup. Contoh pigmen adalah Fast yellow $\mathrm{G}$ (kuning), Toluidine marron (merah) dan Phthalocyanine blue (biru), Zinc Oxide dan Titanium Oxide. Sedangkan yang termasuk dalam ekstender atau pengisi (filler) antara lain; Calcium carbonates, Kaolin dan Magnesium cilicate (Susyanto, H., 2007).

Ekstender atau filler biasanya ditambahkan ke dalam cat dengan tujuan untuk menurunkan harga namun demikian ada juga yang penambahannya ditujukan untu memperbaiki sifat cat, misalnya untuk menurunkan refractive index (indeks pantul) atau meningkatkan daya tutup. Berdasarkan ada tidaknya pigmen inilah cat dan pernis dibedakan. Pernis adalah jenis pelapis (coating) yang trasparan dan tidak mengandung pigmen. Solvent berperan mengatur kekentalan bahan cat agar pas atau mudah diproses baik dalam pembuatan seperti pengadukan, pencampuran, penggilingan dan lain-lain atau dalam pengaplikasian seperti penguasan, penyemprotan atau pelaburan. Hal penting lain yang ada kaitannya dengan peran ini adalah kemampuan solvent untuk melarutkan resin, kemudian membentuk larutan yang stabil dan homogen.

\section{PEMBUATAN CAT}

Teknologi pembuatan cat dapat bervariasi dari yang sederhana sampai ke yang canggih dan semuanya itu akan terkait dengan kualitas hasil, proses maupun penggunaannya (peruntukan cat seperti cat kayu, besi dan lain-lain). Umumnya proses diawali dengan persiapan resep, penyediaan bahan dan pengujian kualitas bahan. Setelah itu tergantung apakah cat yang akan dibuat menggunakan pigmen atau tidak.

Pada pembuatan cat dengan pigmen atau ekstender, ukuran bahan padat yang akan didispersikan (disebarkan keseluruh bahan cat) mempengaruhi proses selanjutnya. Jika ukuran partikel yang diharapkan adalah halus ( $5-20$ mikron), maka diperlukan proses penggilingan partikel padat. Untuk memudahkan proses pembuatan cat, biasanya pigmen, ekstender, sebagian resin dan bahan tambahan terlebih dahulu dijadikan pasta. Beberapa alat yang dapat digunakan untuk menggiling adalah ball mill atau triple roll mill. Pengujian mencakup uji kualitas pendahuluan dan tahap pengujian kualitas cat.

\section{METODOLOGIPENELITIAN}

- Bahan : Damar, Titanium dioksida $\left(\mathrm{TiO}_{2}\right)$, Seng oksida $(\mathrm{ZnO})$, Kaolin $\left(\mathrm{Al}_{2} \mathrm{O}_{3} \cdot 2 \mathrm{SiO}_{2} \cdot 2 \mathrm{H}_{2} \mathrm{O}\right)$, Pigmen, Fast yellow G (kuning), Pigmen, Toluidine marron (merah), Pigmen, Phthalocyanine blue (biru), Terpentin, ThinnerAdan B

- Alat : Hot plate, Electric Stirrer, Bola-bola penggiling, Timbangan, Pengaduk, Termometer, Berbagai wadah untuk proses pencampur-an, penggilingan dan pengemasan, Beaker glass

- Prosedur Penelitian / Pekerjaan

Tahap-tahap kegiatan pembuatan cat

- Penyiapan peralatan proses, lembar kerja dan bahan-bahan proses

- Pemrosesan bahan cair dengan menimbang damar yang berbentuk serbuk sebanyak yang ditentukan dalam lembar komposisi bahan cat ke dalam beaker glas $100 \mathrm{ml}$

- Penambahan terpentin yang sesuai dengan komposisi, pengadukan dan pemanasan

- Selanjutnya bahan bukan cair dan bahan cair dicampur, diaduk dan digiling

- Cat dianggap telah siap dan dapat dikemas serta disimpan 
Tahapan kegiatan aplikasi cat (penggunaan dan pengujian cat)

- Pengimpanan 5 bulan

- Penambahan 40 gram Thinner Aatau B sesuai dengan rancangan perlakuan

- Pengadukan campuran cat dan Thinner hingga kekentalan, warna dan bahan-bahannya merata

- Aplikasikan cat dengan kuas ke bidang cat yang diinginkan

Berikut ini adalah gambaran umum pekerjaan-pekerjaan dalam kegiatan penelitian ini.

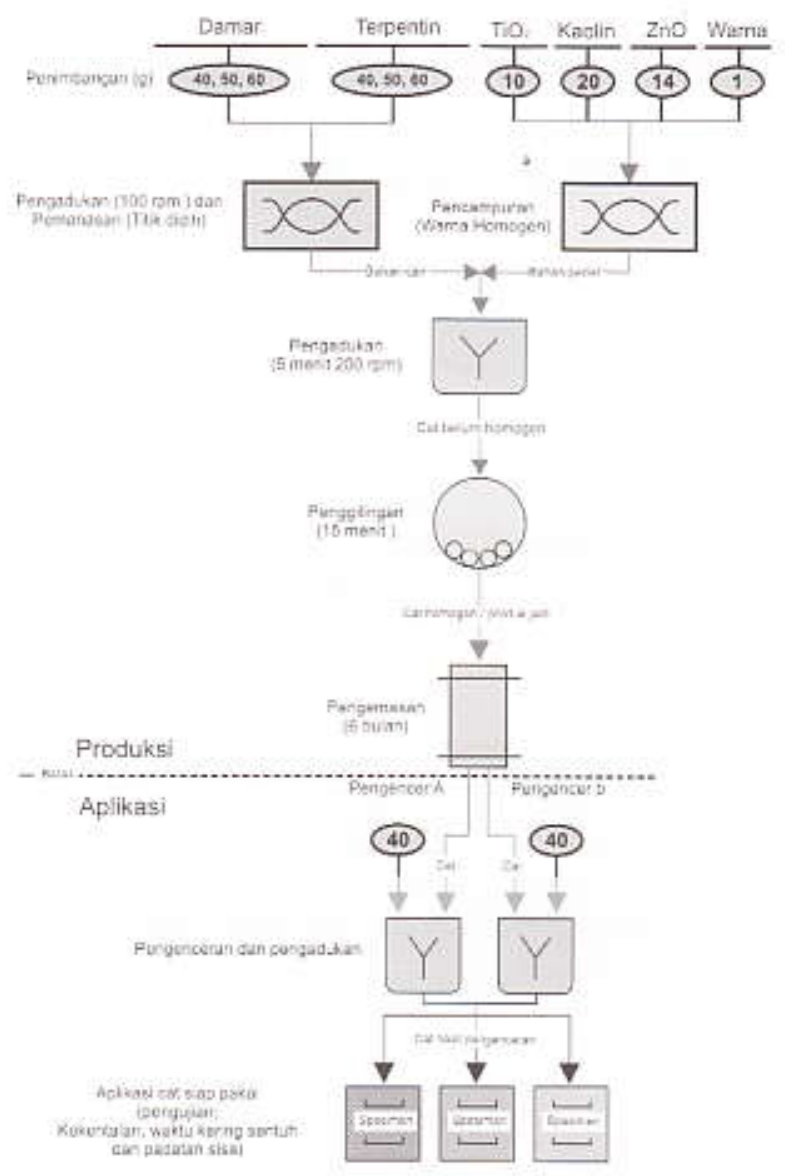

\section{- Pengumpulan Data dan Analisa}

Percobaan dirancang menggunakan rancangan acak berblok dengan 2 (dua) jenis Thinner (A dan B) sebagai blok dan 3 (tiga) perlakuan persentase damar dalam bahan cair $(40,50$ dan $60) \%$ ). Data dikumpulkan dari 4 (empat) kali ulangan percobaan dan hasil pengamatan (pengujian) sifat-sifat kekentalan, waktu kering sentuh dan padatan sisa.

\section{HASIL DAN PEMBAHASAN}

Secara umum pembuatan cat dalam percobaan ini didasarkan pada teknik pembuatan cat berbahan alkid resin dan pembuatan vernis. Sebagai pembeda utama, percobaan ini menggantikan kedudukan alkid resin dengan damar dan menambahkan bahan padat pewarna pada proses vernis. Sedangkan perbedaan dari sisi proses dilakukan dalam penyiapan bahan cair. Persiapan bahan cair dilakukan langsung dengan pencampuran dan pelarutan damar dalam terpentin. Selain itu proses pembuatan cat ini juga dilakukan dengan menggunakan pengaduk dan penggiling sederhana yang memungkinkan hasilnya tidak maksimal dan kualitas kehalusan tidak setara dengan produk-produk buatan pabrik. 
Percobaan dalam penelitian ini hanya menggunakan damar yang diperoleh dipasaran (dalam bentuk tepung) dan dapat dikatakan masuk kategori damar asalan karena diolah (dijadikan tepung) dari campuran berbagai jenis damar yang kualitasnya relatif tidak baik. Namun demikian beberapa contoh damar hitam dan kuning (mata kucing) diuji juga sifat persyaratan umumnya. Hasil uji menunjukan bahwa sifat bilangan asam dan kadar abu damar asalan ini memenuhi persyaratan umum SNI Damar, tetapi tidak untuk sifat titik lunaknya. Secara berurutan nilai titik lunak, bilangan asam dan kadar abu damar ini adalah $150^{\circ} \mathrm{C} ; 22,5$ dan $2.62 \%$. Sedangkan persyaratan umum dalam SNI adalah $95^{\circ} \mathrm{C}-120^{\circ} \mathrm{C}$ untuk titik lunak, $19-36$ untuk bilangan asam dan $0,50 \%-4,00 \%$ untuk kadar abu.

Secara umum cat yang dihasilkan masuk dalam ketegori cat berbahan dasar minyak tipe 3 (tidak terang) kelas A (sedang). Rata-rata hasil percobaan memiliki sifat sebagaimana disajikan pada Tabel komposisi produk cat hasil percobaan. Produk cat ini telah menunjukan sifat kestabilan dalam penyimpanan yang baik karena tidak mengandung atau terjadi endapan dan gumpalan, tidak mengulit, tidak ada pemisahan warna dan dapat diaduk setelah masa penyimpanan selama 6 (enam) bulan.

Tabel komposisi produk cat hasil percobaan

\begin{tabular}{|l|l|c|c|}
\hline \hline No. & Pengujian & Satuan & Nilai rata-rata \\
\hline 1. & Pigmen & $\%$ berat & 31 \\
\hline 2. & Bahan cair & $\%$ berat & 69 \\
\hline 3. & Bahan cair yang tidak menguap & $\%$ berat & 54 \\
\hline 4. & Berat per liter (minimum) & Lbs atau Kg & 10,5 atau 4,76 \\
\hline 5. & Kekentalan & $\mathrm{Ku}$ & 72,5 \\
\hline \hline
\end{tabular}

\section{Hasil uji perlakuan-perlakuan dalam percobaan}

Hasil uji sifat-sifat kekentalan, waktu kering sentuh dan padatan sisa mencoba menggambarkan pengaruh dan keterkaitan dari perlakuan-perlakuan dalam percobaan terhadap sifat-sifat tersebut.

Grafik hasil uji kekentalan memplot nilai kekentalan baik dalam kaitannya dengan jenis pengencer maupun dengan persentase damar. Grafik berikutnya menunjukan adanya hubungan kecenderungan positif yang cukup kuat antara perlakuan persentase damar dengan hasil uji kekentalan pada tingkat kepercayaan 99\% dengan koefisien korelasi 0,76 dan persamaan; Kekentalan $=-4,52293+0.219375^{*}$ Persentase damar. Sedangkan tabel nilai kekentalan rata-rata dari berbagai perlakuan dan kelompok ditampilkan setelah grafik tersebut.

Grafik hasil uji kekentalan

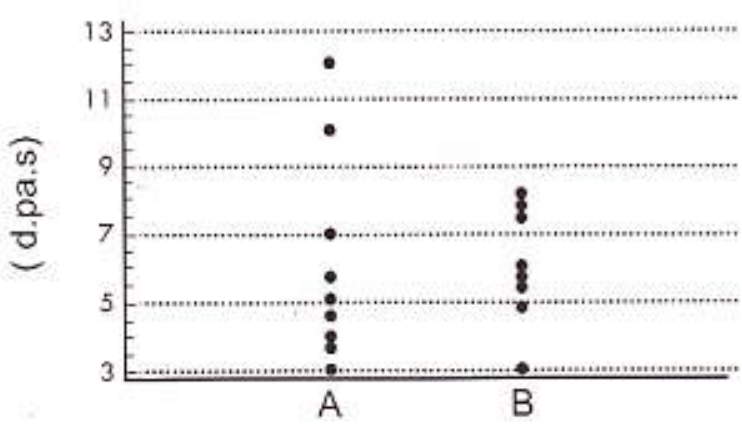

Jenis Pengencer

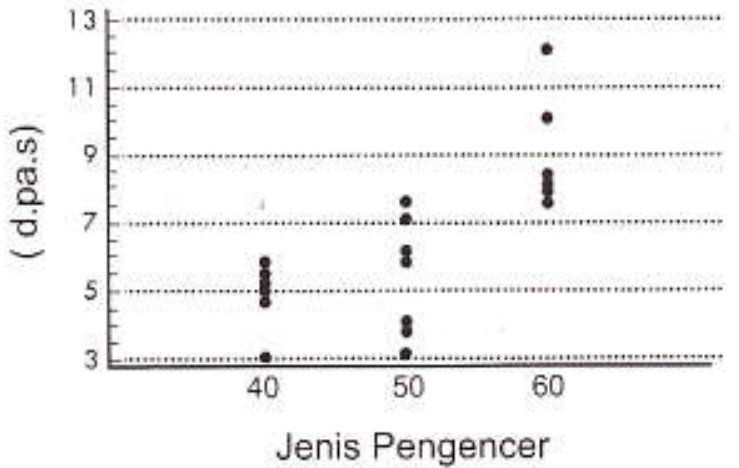


Grafik kecenderungan persentase damar dan kekentalan

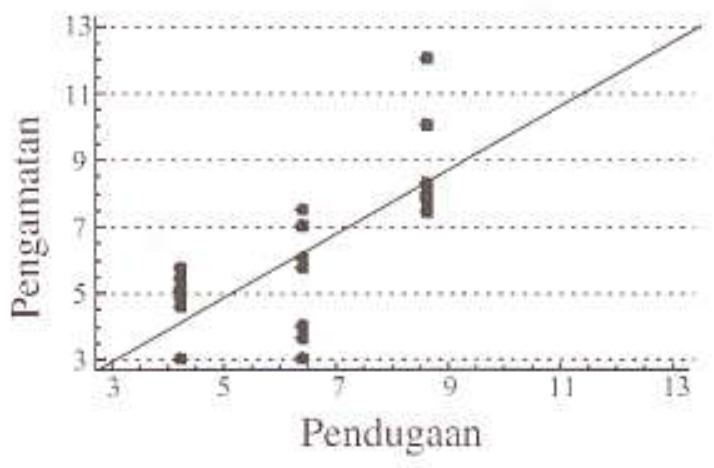

\begin{tabular}{|c|c|c|c|c|c|}
\hline \hline Tingkat & Jumlah & Rata-rata & Galat baku & $\begin{array}{c}\text { Batas } \\
\text { bawah }\end{array}$ & Batas atas \\
\hline Rata-rata total & 24 & 6,44583 & & & \\
\hline Jenis Pengencer & & & & & \\
\hline A & 12 & 6,66667 & 0,404858 & 5,82215 & 7,51119 \\
\hline B & 12 & 6,225 & 0,404858 & 5,38048 & 7,06952 \\
\hline Persentase damar & & & & & \\
\hline 40 & 8 & 4,8 & 0,495847 & 3,76568 & 5,83432 \\
\hline 50 & 8 & 5,35 & 0,495847 & 4,31568 & 6,38432 \\
\hline 60 & 8 & 9,1875 & 0,495847 & 8,15318 & 10,2218 \\
\hline \hline
\end{tabular}

Grafik hasil uji waktu kering sentuh memplot nilai waktu kering sentuh baik dalam kaitannya dengan jenis pengencer maupun dengan persentase damar. Sedangkan nilai rata-rata waktu kering sentuh dari berbagai perlakuan dan kelompok dapat dilihat pada tabel berikutnya.

Grafik hasil uji waktu kering sentuh

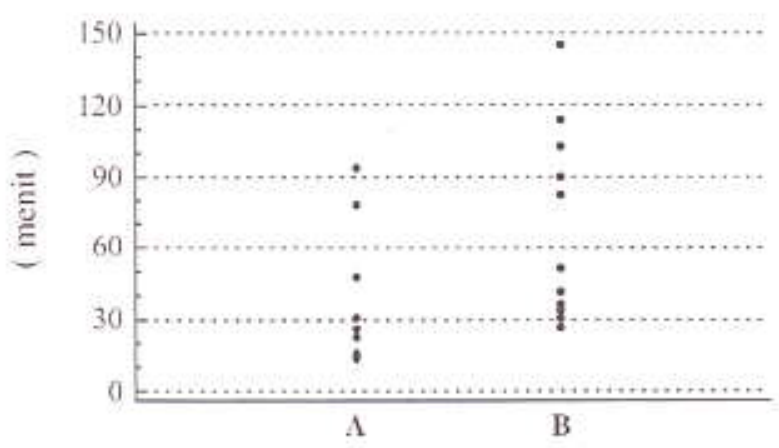

Jenis Pengencer

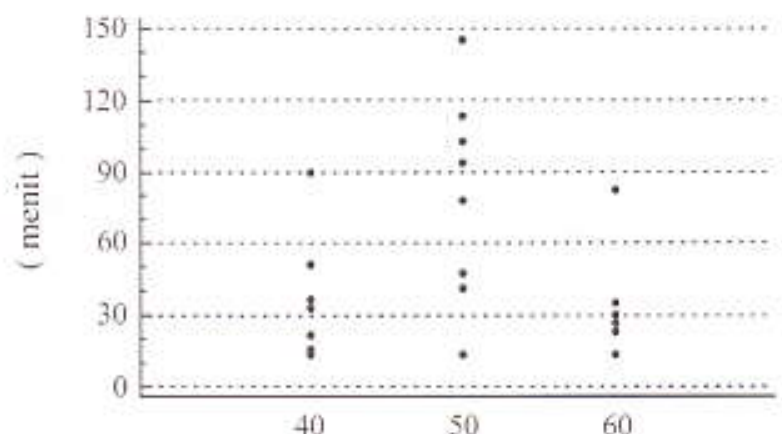

Presentase Damar

Tabel nilai rata-rata hasil uji waktu kering sentuh

\begin{tabular}{|c|c|c|c|c|c|}
\hline \hline Tingkat & Jumlah & Rata-rata & Galat baku & Batas bawah & Batas atas \\
\hline Rata-rata total & 24 & 49,0417 & & & \\
\hline Jenis Pengencer & & & & & \\
\hline A & 12 & 32,6667 & 7,65398 & 16,7007 & 48,6326 \\
\hline B & 12 & 65,4167 & 7,65398 & 49,4507 & 81,3826 \\
\hline Persentase damar & & & & & \\
\hline 40 & 8 & 34,75 & 9,37417 & 15,1958 & 54,3024 \\
\hline 50 & 8 & 79,0 & 9,37417 & 59,4458 & 98,5542 \\
\hline 60 & 33,375 & 9,37417 & 13,8208 & 52,9292 \\
\hline \hline
\end{tabular}


Hasil uji waktu kering sentuh sebagaimana halnya dengan hasil uji padatan sisa tidak menggambarkan adanya hubungan yang signifikan dengan perlakuan persentase damar. Hal ini ditunjukan dengan relatif lemahnya koefisien korelasi ( $r$ ) antara variable-variabel tersebut, masingmasing ( $r$ ) nya adalah $-0,0155506$ dan 0,205925 . Grafik hasil uji padatan sisa memplot nilai padatan sisa baik dalam kaitannya dengan jenis pengencer maupun dengan persentase damar. Nilai ratarata padatan sisa dari berbagai perlakuan dan kelompok dapat dilihat pada tabel setelah grafik tersebut.

Grafik hasil uji padatan sisa

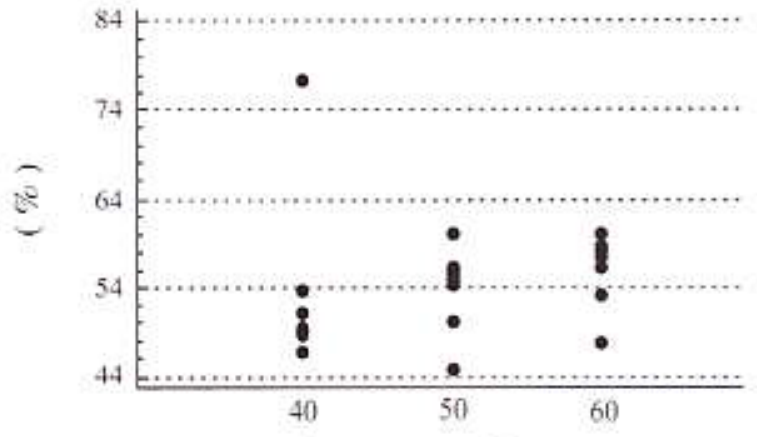

Presentase Damar

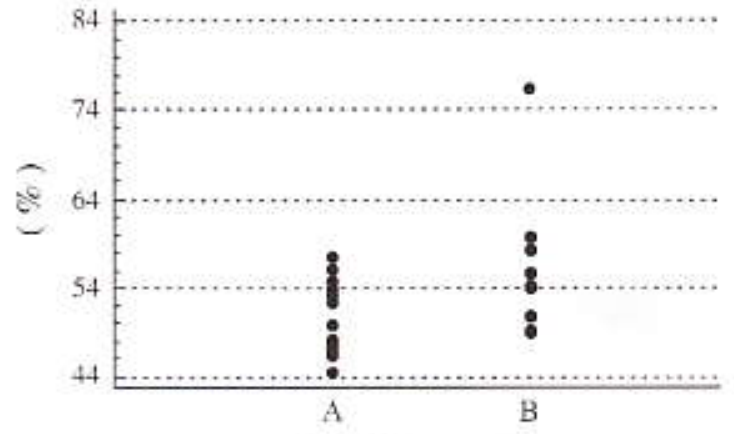

Jenis Pengencer

Tabel nilai rata-rata hasil uji padatan sisa

\begin{tabular}{|c|c|c|c|c|c|}
\hline \hline Tingkat & Jumlah & Rata-rata & Galat baku & Batas bawah & Batas atas \\
\hline Rata-rata total & 24 & 54,2296 & & & \\
\hline Jenis Pengencer & & & & & \\
\hline A & 12 & 51,3225 & 1,77834 & 47,6129 & 55,0321 \\
\hline B & 12 & 57,1367 & 1,77834 & 53,4271 & 60,8426 \\
\hline Persentase damar & & & & & \\
\hline 40 & 8 & 52,8325 & 2,17801 & 48,3892 & 57,4758 \\
\hline 50 & 8 & 53,5512 & 2,17801 & 49,008 & 58,0945 \\
\hline 60 & 8 & 56,205 & 2,17801 & 51,6617 & 60,7483 \\
\hline \hline
\end{tabular}

\section{Produk cat dari damar}

Dari uraian hasil penelitian tersebut diatas, jelas terlihat bahwa damar dapat dibuat menjadi cat meskipun dalam percobaan ini cat yang dihasilkan baru masuk dalam kategori cat berbahan dasar minyak tipe 3 (tidak terang) kelas A (sedang). Hal ini sesuai pernyataan Formo (1979) dan Lin (1992) bahwa damar merupakan salah satu resin alam yang dapat dijadikan bahan dalam pembuatan cat, terutama ketika Alkid Resin belum ditemukan sekitar lebih dari setengah abad yang lalu. Sifat utama dari damar yang diperlukan dalam pembuatan atau dalam produk cat adalah daya ikatnya. Kemampuan mengikat damar baik terhadap sesama bahan cat lainnya maupun terhadap bahan yang akan dilapisi timbul setelah damar terlarut dalam terpentin dan membentuk bahan cair cat.

Dengan adanya kemampuan mengikat ini, produk cat dari damar juga berperilaku sebagaimana cat berbahan dasar minyak lainnya, terutama sifat kestabilan produk cat ketika disimpan dan perilaku polimerisasi dan penebaran pigmen ketika cat diaplikasikan. Sifat dan perilaku-perilaku ini telah ditunjukan oleh produk cat dari damar, semua produk (dari semua perlakuan dan ulangan) telah lolos uji masa simpan 6 bulan dan produk cat dari damar juga berpolimerisasi, mengering membentuk film (lapisan tipis) yang keras, lekat, tidak tembus air, tahan gesekan dan memiliki kemampuan menutup warna dasar bahan uji (specimen yang terbuat dari kayu lapis).

Analisa tentang kestabilan produk tersebut diatas sejalan dengan pendapat Anonim (2007) yang menyatakan bahwa dalam pembuatan cat ada proses pembasahan dan penebaran pigmen 
secara merata keseluruh bahan cat yang dapat menjaga agar kondisi cat tetap stabil. Sedangkan bahasan tentang polimerisasi dan seterusnya sesuai dengan pendapat Lin (1992) dan Anonim (2007). Keduanya sama-sama berpendapat bahwa tidak seperti cat berbasis air, cat minyak tidak mengering hanya karena evaporasi melainkan juga karena terjadinya polimerisasi. Dalam polimerisasi, sebagai hasil proses oksidasi, oksigen memutus rantai hidrokarbon dan memicu reaksi-reaksi lanjutan yang membentuk molekul berantai panjang.

Ketika polimerisasi berlangsung, terjadi pula proses pengeringan atas sejumlah bahan yang tidak berkontribusi dalam proses polimerisasi. Bahan-bahan ini termasuk hydroperoxide $(\mathrm{ROOH})$ yang tidak stabil, hasil samping utama dari reaksi antara oksigen dan asam-asam lemak tidak jenuh. Hidroperoxide terurai membentuk karbon dioksida, air, berbagai aldehid, asam dan hidrocarbon yang umumnya merupakan zat terbang.

\section{Pembuatan cat dari damar}

Proses pembuatan cat dari damar ini sebenarnya termasuk proses yang sederhana. Kesederhanaan utamanya disebabkan karena proses pembuatan cat dalam penelitian ini diawali dari resin alam (damar) yang sudah tersedia sedangkan pada proses acuan dimulai dari proses pembuatan resin sitetisnya (alkid resin). Hal lain yang membuatnya sederhana adalah karena hanya melibatkan 2 (dua) proses utama; pelarutan damar dalam terpentin untuk penyiapan bahan cair cat dan penggilingan bahan padat pigmen didalam koloid bahan cair cat.

Proses ini memerlukan pemanasan hingga mendidih $\left( \pm 105^{\circ} \mathrm{C}\right)$ dalam pelarutan damar agar prosesnya cepat dan sempurna dan penggilingan yang benar-benar menggilas seluruh bahan cat, terutama bahan padat (pigmen). Idealnya proses penggilingan ini menggunakan alat khusus untuk menggiling dalam pembuatan cat yang salah satunya disebut Ball Mill. Karena ketiadaan alat khusus ini, dalam percobaan digunakan gabungan alat pengaduk dan bola-bola besi penggiling yang fungsinya serupa dengan Ball Mill. Hasil aplikasi menunjukkan adanya bagian kasar dan tidak rata (tampak ada butir-butir kecil yang tidak merata) pada spesimen yang dicat dengan cat buatan percobaan ini, sementara kekurangan ini tidak tampak bila cat produk pabrik digunakan.

\section{Kekentalan}

Kekentalan adalah salah satu sifat cat yang diamati variasi dan keterkaitannya dengan perlakuan-perlakuan dalam percobaan. Sifat ini dapat mengindikasikan tebal lapisan atau tingkat polimerisasi dan tingkat kemudahan dalam pengaplikasian cat ke contoh uji. Kemungkinan adanya variasi sifat kekentalan ini dianalisa dengan menggunakan analisa keragaman. Hasil analisa menunjukan bahwa hanya faktor B (Persentase damar) saja yang secara statistika memberikan pengaruh yang signifikan terhadap sifat kekentalan.

Uji lanjut dengan Multiple Range Test (MRT) menunjukkan bahwa tidak ada perbedaan yang signifikan antara perlakuan Persentase damar $40 \%$ dengan $50 \%$ terhadap sifat kekentalan, namun perbedaan yang signifikan ada pada Persentase damar $40 \%$ dengan $60 \%$ dan antara $50 \%$ dengan $60 \%$. Jadi jika dilihat dari sisi kekentalan, maka perlakuan yang disarankan untuk digunakan adalah perlakuan Persentase damar $50 \%$ karena $50 \%$ adalah jumlah damar minimum yang diperlukan untuk menghasilkan kekentalan yang paling mendekati standard. Dengan tidak memperhatikan faktor A (Jenis Pengencer), nilai kekentalan rata-rata secara keseluruhan dari perlakuan Persentase damar $50 \%$ adalah 5,35 d.Pa.s atau setara dengan $69 \mathrm{Ku}$ dan ini hanya terpaut 1 nilai dari standar terendah 70 .

\section{Waktu kering sentuh}

Umumnya pengguna cat menginginkan cat yang cepat kering atau Waktu kering sentuh yang lebih cepat. Namun sebagian orang justru menginginkan sebaliknya karena mereka percaya semakin cepat kering akan menurunkan sifat kilap hasil pengcatan. Terlepas dari perbedaan pandangan ini dan ketiadaan data akurat untuk membenarkan salah satunya, penelitian ini menganggap sifat Waktu kering sentuh bersifat pilihan (pengguna dapat memilih apa saja). Tetapi 
informasi tentang sifat Waktu kering sentuh tetap diperlukan untuk dasar menjatuhkan pilihan.

Hasil uji menunjukkan bahwa kelompok $\mathrm{A}$ (Jenis Pengencer) maupun perlakuan $\mathrm{B}$ (Persentase damar) mempengaruhi secara nyata nilai Waktu kering sentuh dan untuk itu perlu dilakukan uji lanjut. Hasil uji lanjut ini menunjukan bahwa kelompok Jenis pengencer $A$ dan $B$ mempengaruhi Waktu kering sentuh secara signifikan dan dalam hal ini Waktu kering sentuh Jenis pengencer $A$ jauh lebih lebih cepat $(32,7)$ menit dari Jenis pengencer $B(65,4)$ menit. Berdasarkan uaraian ini, disarankan untuk menggunakan Jenis pengencer A dan Persentase damar $50 \%$.

\section{Padatan sisa}

Padatan sisa dapat merupakan indikator besarnya jumlah zat terbang (volatile organic compound/VOC). Kecenderungan yang ada saat ini adalah pengaturan pembatasan besarnya VOC karena alasan kesehatan dan lingkungan, jadi sebaiknya jumlah VOC sesedikit mungkin dan itu berarti padatan sisa kalau bisa sebesar-besarnya. Standard yang ada membatasi jumlah minimalnya dengan nilai 50\% (SNI 06-4827-1998). Hasil ini menunjukan bahwa hanya kelompok Jenis pengencer saja yang memiliki pengaruh signifikan terhadap sifat Padatan sisa. Hal ini menjadi sangat jelas karena sumber VOC utama dalam produk cat ini adalah bahan pengencer yang sangat mungkin mengandung etil benzene, toluene, benzene dan bahan aromatic lainnya yang emisinya dapat mengganngu kesehatan dan lingkungan (Anonim, 1978). Selanjutnya pada uji lanjut dapat dinyatakan bahwa Jenis pengencer A dan Jenis pengecer B adalah berbeda secara signifikan. Dengan nilai rata-rata masing-masing secarat berurutan adalah $51,32 \%$ dan $57,14 \%$. Dan oleh karenanya untuk pertimbangan kesehatan dan keselamatan lingkungan disarankan untuk menggunakan Pengencer jenis $\mathrm{B}$.

\section{Prospek Industri cat dari damar}

Berdasarkan bahasan-bahasan diatas bahwa secara teknis pembuatan pembuatan cat berbasis minyak dengan bahan damar adalah layak untuk tipe 3 (tidak terang) kelas A (sedang). Dari segi biaya produksi diperkirakan ongkosnya mencapai Rp. 15.000 ,- per kemasan 250 gram. Meskipun harga ini lebih murah dari produk sejenis di pasaran yang mencapai Rp. 20.000,- tidak serta merta membuat produk ini layak secara ekonomis. Hal ini memerlukan kajian yang lebih dalam lagi untuk dapat dikatakan layak secara ekonomis apalagi untuk skala industri meskipun itu industri kecil. Kendala utama yang harus diatasi jika akan diproduksi secara masal adalah jumlah dan sebaran damar yang siap digunakan secara kontinyu dan dalam jumlah yang besar. Sejauh survei yang telah dilakukan dalam penelitian ini, sulit mendapatkan data damar, damar itu sendiri dan pemasoknya di wilayah Provinsi Kalimantan Timur ini. Kendala lain adalah peralatan produksi skala industri yang data dan analisisnya belum ada. Jadi sementara ini dapat disimpulkan bahwa industri cat dari damar di Kalimantan Timur.

\section{KESIMPULAN DAN SARAN}

Penelitian ini menyimpulkan dua hal; pertama adalah secara teknis damar dapat dibuat menjadi cat dengan teknik pembuatan yang disarankan dalam penelitian ini dengan hasil cat berbahan dasar minyak kategori tipe 3 (tidak terang) kelas A (sedang) dan yang kedua adalah persentase damar $50 \%$ dan jenis bahan pengencer $B$ merupakan pilihan terbaik untuk membuat dan mengaplikasikan cat dari damar.

Studi kelayakan ekonomis termasuk survey potensi damar sangat diperlukan jika ada kebijakan untuk mendorong tumbuhnya industri cat berbahan damar di Kalimantan Timur. 


\section{DAFTAR PUSTAKA}

Anonim, 2007. Oil Paint. http:/en.wikipedia.org/wiki/Oil_Paint dikunjungi pada tanggal 5 Maret 2007.

Anonim, 2007. Proses Teknologi Pembuatan Cat. http:/pengecatan.blogspot.com dikunjungi pada tanggal 5 Maret 2007.

Anonim, 1978. Federal Specification. Thinner, Paints, Mineral Spirits, Regular and Odorless. USA.

Formo, MW., 1979. Paints, Varnishes and Related Products, in Bailey's Industrial Oil and Fat Products, Fourth Edition, ed. Daniel Swern. John Wiley \& Sons. New York. USA.

ICIP, 1998. Cleaner Production Assessment for Paint Production, A Case Study. Indonesia Cleaner Industrial Production Program. Jakarta. Indonesia.

ITW Ransburg, 2006. Paint, High Voltage and SCI Test Equipment, Service Manual, Illinois Tool Work Inc. Illinois. USA.

Lin K.F., 1992. Alkyd Resin, in Kirk-Othmer Encyclopedia of Chemical Technology, Fourth Edition, ed. Kroschwitz J.I. and Mary Howe-Grant. John Wiley \& Sons. New York. USA.

Miller I, John E. F and Richard A. Johnson, 1990. Probability and Statistic for Engineers, Fourth Edition. Prentice-Hall International, Inc. New Jersey. USA.

SNI , 1998. SNI - 06-4827-1998, Spesifikasi campuran cat siap pakai berbahan dasar minyak. Badan Standardisasi Nasional. Jakarta. Indonesia.

Secrest, 2007. How Paint is Made. http:/www.madeshow.com/volume-1/Paint.html dikunjungi pada tanggal 5 Maret 2007.Susyanto, H., 2007. Tentang Cat. http://www.geocities.com/heri_susyanto/ApakahCat.htm dikunjungi pada tanggal 5 Maret $200 \overline{7}$.

Syahruddin, MS., Fauziati, Bachtiar Efefendi dan Sabriansyah, 1991. Penelitian Berbagai Jenis Damar Kaltim untuk dibuat menjadi Dempul. Proyek Penelitian dan Pengembangan Industri Provinsi Kalimantan Timur. Departemen Perindustrian. Samarinda

Syahruddin, MS., Fauziati, Yusuf Ansori, Sabriansyah dan Suroto, HS., 1992. Penelitian Pembuatan Terpentin dari Damar Kalimantan Timur. Proyek Penelitian dan Pengembangan Industri Provinsi Kalimantan Timur. Departemen Perindustrian. Samarinda.

Zulnely, AH Lukman dan NW Siregar, 1994. Karakteristik Damar dan Pemanfaatannya. Proceeding. Diskusi Hasil Penelitian. Pusat Penelitian dan Pengembangan Hasil Hutan. Bogor. Indonesia. 